\title{
EFIKASI DIRI UNTUK MENINGKATKAN OPTIMISME TERHADAP PENCAPAIAN KARIR KARYAWAN PKWT PERUSAHAAN X
}

\section{SELF EFFICACY TO INCREASE CAREER OPTIMISM ON EMPLOYEE CONTRACT (PKWT)}

\author{
Rocky Valentino \\ Fakultas Psikologi dan IImu Sosial Budaya Universitas Islam Indonesia, Yogyakarta \\ Email: rocky-consulting@yahoo.com \\ Fathul Himam \\ Fakultas Psikologi, Universitas Gadjah Mada, Yogyakarta
}

\begin{abstract}
The aim of this research was to study the effectiveness of self efficacy in increasing the employee's career optimism. The hypothesis in this study was there is an increase of employee's career optimism on experiment group after their participation in the self efficacy training. The employees are expected to understand the concept of self-efficacy and career optimism to improve their future career achievement at work. The research used one group pretest and posttest design. Fifty employees participated in the self efficacy training. There are 29 male and 21 female. The measures are used career optimism scale and self efficacy scale. Career optimism scale refers to Rottinghaus, Day, and Borgen's theory (2005). Self Efficacy scale refers to bandura's theory $(1982,1993,1997,2006)$. The statistical result shows 3,595 point and $p=$ $0,001(p<0,05)$ with paired sample t-Test. This means there is a difference in the level of career optimism employees on experiment group before and after participate in self efficacy training. Self efficacy training was effective to increase the employees career optimism at work.
\end{abstract}

\section{ABSTRAK}

Penelitian ini bertujuan untuk menguji peningkatan optimisme pencapaian karir melalui_pelatihan efikasi diri pada karyawan PKWT Perusahaan X. Hipotesis pada penelitian ini adalah ada peningkatan ptimisme pencapaian karir karyawan setelah diberikan pelatihan dengan konsep efikasi diri. Metode penelitian ini adalah eksperimen dengan desain one group pretest and posttest. Subjek penelitian ini adalah karyawan PKWT Perusahaan X berjumlah 50 responden, terdiri dari 29 laki-laki dan 21 perempuan. Alat ukur yang digunakan adalah Angket optimisme pencapaian karir pada aspek-aspek yang dikemukakan oleh Rottinghaus, Day, dan Borgen (2005) dan Angket efikasi diri dengan mengacu pada aspek-aspek yang dituliskan oleh Bandura (1982, 1993, 1997, 2006). Metode Analis data yang digunakan paired sample $t$ Test. Hasil penelitian menunjukkan bahwa ada perbedaan yang signifikan terhadap peningkatan optimisme pencapaian karir sebelum dan sesudah diberikan pelatihan efikasi diri.

Kata Kunci: Efikasi Diri, Optimisme, Karir, Karyawan 
Organisasi memiliki fungsi vital dalam menyelaraskan interaksi perangkat (sistem) dan keterlibatan orang di dalamnya. Sumber Daya Manusia (SDM) menjadi modal penggerak yang dinamis dalam pencapaian tujuan. Dinamika perubahan jaman yang terus mengalami kemajuan berpengaruh terhadap perkem-bangan organisasi. Mathis dan Jackson (2001) menuliskan bahwa sumber daya manusia dipandang semakin besar peranannya bagi kesuksesan organisasi. Tantangan dan persaingan bisnis antara perusahaanperusahaan maju sudah menempatkan peranan vital karyawan sebagai fungsi human capital bagi kelangsungan bisnis jangka panjang. Fungsi strategis SDM memiliki peran penting dalam mengembangkan karya-wan sebagai aset penting untuk memberikan kontribusinya pada jenjang karir di dalam organisasi.

Isu-isu strategis yang berkembang dalam human capital adalah karyawan sebagai aset bagi perkembangan organisasi (Luthans, Luthans, \& Luthans, 2004). Penelitian-penelitian yang berkaitan dengan manajemen SDM mengarah pada tantangan-tantangan strategis kualitas tenaga kerja (Mathis \& Jackson, 2000). Perusahaan yang memandang pentingnya faktor human capital memiliki sistem pengelolaan SDM dalam melejitkan karir karyawannya. Karyawan diharapkan mampu berkarir dengan menunjukkan performa diri yang optimal. Performa dan potensi tersebut memengaruhi kesuksesan karir di tempat kerja (Friedman, Kane \&
Cornfiled, 1998; Luthans, Avolio, Walumbwa, \& Li , 2005; Winarno, 2007). Isu-isu penting berkaitan dengan kesuksesan dan karir seseorang dalam pekerjaan berorientasi pada psikologi positif di tempat kerja semakin berkembang (Avey, Luthans \& Jensen, 2008). Psikologi positif yang dimaksud dapat berupa keyakinan diri, harapan, optimis dan resiliensi (Luthans, 2002; Avey, Luthans, \& Jensen, 2008; Avey, Reichard, Luthans \& Mhatre, 2011). Perlunya keyakinan, harapan, optimis, dan resiliensi dapat dimiliki karyawan untuk menciptakan kinerja yang maksimal (Mortazavi, Yazdi \& Amini, 2012).

Optimisme merupakan variabel penting dalam memengaruhi kesuksesan pekerjaan (Kalnbach \& Lantz, 1997). Kesuksesan dalam pekerjaan yang dimaksud adalah pencapaian performa, prestasi dan karir (Wright, 2003). Karir merupakan variabel penting dalam pencapaian tujuan di dalam pekerjaan. Pencapaian karir tersebut memerlukan usaha-usaha maksimal dari karyawan, termasuk dalam hal ini adalah keyakinan terhadap karir (Bezt \& Hacket, 2006). Karyawan lebih melihat faktor pencapaian karir dalam pekerjaannya.

Pentingnya pencapaian karir di tempat kerja menciptakan tantangantantangan penelitian masa depan dalam perkembangan intervensi kesuksesan karyawan di tempat kerja. Intervensi psikologi positif dapat meningkatkan performa kerja karyawan (Luthans, Avey, Avolio, Norman \& Combs, 2006; 
Luthans, Norman, Avolio, \& Avey, 2008; Luthans, Avey, Avolio, \& Peterson, 2010). Intervensi berupa pelatihan psychological capital dapat memberikan kontribusi terhadap manajemen stres karyawan (Avey, Luthans, \& Jensen, 2008). Menurut Bandura (1993) dan Owre (2005), efikasi diri merupakan model intervensi untuk pencapaian keberhasilan. Model intervensi pelatihan efikasi diri kreatif dapat meningkatkan pencapaian keberhasilan dan performa kelompok karyawan (Mathisen \& Bronnick, 2009)

Optimisme dalam pencapaian karir perlu dimiliki oleh setiap karyawan untuk memelihara sikap positif terhadap karir yang ingin dicapainya. Rottinghaus, Day, dan Borgen (2005) menjelaskan bahwa optimisme berkaitan dengan pengaturan diri dalam pencapaian tujuan serta bagaimana harapan yang dimiliki memengaruhi tujuan yang ingin dicapai. Optimisme dapat memunculkan energienergi positif di tempat kerja (Luthans, 2002; Luthans, Avolio, Walumbwa, \& Li, 2005; Luthans \& Youssef, 2007). Awal karir seseorang dimulai dengan menjadi karyawan baru. Masa tersebut merupakan gerbang awal seseorang dalam mengawali perjalanan karir seseorang.

Sistem karyawan baru di perusahaan tidak lepas dari status karyawan kontrak. Karyawan kontrak pada dasarnya dikenal dalam sistem perundang-undangan ketenagakerjaan Indonesia sebagai karyawan dengan Perjanjian Kerja Waktu Tertentu (PKWT). Banyak dijumpai kasus karyawan yang mengalami putus kontrak ataupun tidak dapat melanjutkan kontrak kerjanya. Hal tersebut dipengaruhi oleh adanya kebijakan perusahaan maupun faktor kinerja karyawan. Kebijakan perusahaan berkaitan dengan sistem ketenagakerjaan mengenai perjanjian kerja waktu tertentu (PKWT) sebelum diangkat menjadi karyawan tetap (PKWTT). Faktor kinerja karyawan juga disebut dapat memengaruhi keberlangsungan karir bagi karyawan kontrak. Ketidakmampuan karyawan tersebut dalam beradaptasi dengan tuntutan pekerjaan yang berkaitan dengan prakarir di perusahaan tersebut.

Masa-masa karyawan PKWT merupakan masa-masa yang masih rentan terhadap perjalanan karir karyawan. Pada sistem status kontrak karyawan terdapat kebijakan perusahaan untuk tidak melanjutkan kontrak ataupun mengangkat menjadi karyawan tetap. Terlebih dalam masa karyawan kontrak adalah tahap monitoring dan evaluasi kinerja seseorang terhadap standar tuntutan jabatan di dalam organisasi perusahaan. Oleh karena itu tidak jarang ditemui karyawan dengan kualitas yang masih di bawah standar sehingga mengakibatkan putusnya kontrak kerja.

Rasa ketidaknyamanan terhadap sistem PKWT dapat muncul pada diri karyawan yang kurang memiliki rasa optimis. Ketidaknyamanan (job-insequrity) dalam bekerja dapat menyebabkan karyawan merasa pesimis terhadap kelangsungan karir pekerjaannya ke depan. Secara psikologis ketidaknya- 
manan dalam bekerja dapat membuat karyawan kurang antusias, tidak semangat, bekerja dengan performa biasa saja, adanya kecemasan, serta kurang yakin terhadap karir masa depannya di perusahaan tersebut. Ketidaknyamanan dalam bekerja juga dapat menyebabkan lemahnya komitmen dan menurunnya performa kinerja yang ditunjukan. Faktor tersebut dapat berpengaruh terhadap intensitas turn over.

Permasalahan penelitian yang diungkap adalah rendahnya sikap optimisme dalam pencapaian karir seorang karyawan dalam bekerja khususnya yang berstatus sebagai karyawan PKWT. Hal ini dapat dipengaruhi faktor sistem karir yang tidak sesuai dengan yang diharapkan. Bisa karena keterbatasan terhadap kebijakan sistem karir yang dimiliki perusahaan. Dapat pula tingkat stress yang dialami karyawan karena tidak mampu menerima dan menyesuaikan diri dengan kebijakan sistem karir yang dikembangkan di dalam perusahaan. Hal tersebut dapat dijumpai pada karyawan baru dengan status sebagai karyawan kontrak.

Penelitian Higgins, Dobrow dan Roloff (2010) mengungkapkan permasalahan bahwa situasi yang tidak sesuai dengan prediksi seseorang akan karirnya dapat menyebabkan seseorang stres karena tidak mampu beradaptasi dengan sistem karir yang dihadapi. Oleh karena itu, kondisi tersebut dapat menyebabkan karyawan merasa tidak nyaman, tidak bersemangat, kurang antusias, kurang yakin untuk dapat mengembangkan karirnya, bahkan sering pula dijumpai karyawan yang berpindah-pindah selayaknya "kutu loncat". Data menyebutkan bahwa kasus-kasus yang dijumpai pada karyawan yang sering berpindah-pindah tempat kerja adalah karena masalah kebijakan atasan atau manajemen yang kurang sesuai, kepemimpinan kurang baik, tawaran gaji lebih tinggi, faktor motivasi, jenjang karir tidak jelas, serta minimnya apresiasi (Asri, 2008).

Rendahnya sikap optimis terhadap pencapaian kesuksesan karir di tempat kerja dapat digambarkan dari kondisi ketidaknyamanan seseorang dalam menghadapi kebijakan sistem karir yang kurang optimal, sehingga dapat menghambat keberlangsungan karir karyawan di dalam organisasi. Diungkapkan dari hasil wawancara terhadap karyawan perusahaan bahwa kebijakan sistem kontrak membuat karyawan merasa kurang yakin untuk menjalankan tugas dan pekerjaannya selama kurun waktu dua tahun ke depan. Karyawan menganggap bahwa status kerjanya masih menggantung dengan sistem kontrak yang harus dijalaninya. Karyawan ragu dengan kejelasan statusnya apakah setelah dua tahun kemudian akan diangkat menjadi karyawan tetap ataukah justru diputus kontraknya. Persepsi karyawan terhadap kesuksesan pencapaian karirnya menjadi terhambat dengan adanya ketidakjelasan status kerjanya pada masa mendatang.

Karyawan idealnya harus memiliki optimisme terhadap pencapaian karir di 
perusahaan tempat kerjanya. Optimisme terhadap pencapaian karir atau career optimism adalah persepsi karyawan terhadap situasi karir saat ini terhadap gambaran-gambaran positif tentang harapan, pengaruh motivasi dan perasaan (Friedmen, Kane \& Cornfiled, 1998). Optimisme terhadap pencapaian karir yang dimaksud dalam penelitian ini adalah sikap optimis untuk pencapaian kesuksesan karir. Seseorang yang memiliki optimisme terhadap pencapaian karir akan memiliki pikiran positif tentang kelangsungan karirnya dalam pekerjaannya. Kesuksesan karir seseorang dapat disebabkan perasaan senang, pengaruh emosi positif termasuk nyaman, kepuasan, rasa antusias dan ketertarikan (Lyubomirsky \& Boehm, 2005).

Rottinghaus, Day, dan Borgen (2005) mengungkapkan bahwa variabelvariabel yang dapat memengaruhi optimisme terhadap pencapaian karir antara lain rasa optimis, efikasi diri, pengaruh nilai positif dan negatif dan faktor kepribadian. Efikasi diri merupakan salah satu faktor yang memengaruhi optimisme terhadap pencapaian karir. Bandura (1993) mengartikan efikasi diri sebagai keyakinan manusia pada kemampuan mereka untuk melatih sejumlah ukuran pengendalian terhadap fungsi diri mereka dan kejadian-kejadian lingkungannya. Efikasi diri menyebabkan individu merasa memiliki keyakinan pada kemampuan diri sendiri untuk menghadapi dan memecahkan masalah dengan efektif. Diteruskan dengan meyakini diri sendiri bahwa dirinya mampu mencapai keberhasilan dan sukses pada masa mendatang. Penjelasan efikasi diri dalam perpekstif islam dijabarkan dengan teoriteori yang mendukung dan sejalan dengan konsep efikasi diri yang diuraikan di atas. Sejalan dengan keyakinan diri, Ghazali (1997) mengungkapkan bahwa keyakinan, kemauan dan keimanan adalah suatu hal yang saling berkaitan. Dijelaskan bahwa keyakinan seorang muslim adalah berkaitan dengan akidah untuk beribadah kepada Allah SWT untuk mendapatkan kebahagiaan dunia dan akherat. Proses ibadah tersebut didasari dengan petunjuk-petunjuk yang harus dijalankan oleh seorang muslim. Keyakinan untuk mendapatkan cita-cita mulia tersebut haruslah dilakukan dengan ikhtiar yang kuat untuk dapat mencapai tujuan tersebut.

Penerapan konsep efikasi diri di tempat kerja dikenal dengan istilah career self efficacy. Betz dan Hackett (2006) menjelaskan efikasi diri dalam konteks karir adalah penilaian seseorang terkait dengan kemampuannya untuk memilih, mengembangkan, dan menyesuaikan karirnya. Menurut Bandura (1982, 1993), jika individu yang memiliki efikasi diri dalam karirnya maka akan memengaruhi pembelajarannya dalam bekerja menyelesaikan tugas pekerjaannya, memiliki tujuan yang akan dicapai dengan usaha dan keyakinannya, serta menumbuhkan persistensi dalam menghadapi kesulitan tugas. 
Efikasi diri sangat diperlukan oleh karyawan untuk memengaruhi optimisme terhadap pencapaian karir di tempat kerja. Penelitian Carifio dan Rhodes (2002) mengungkapkan bahwa efikasi diri memiliki korelasi positif dengan variabel optimis. Karyawan memiliki keyakinan untuk terus bekerja dengan baik meskipun dengan kondisi sistem perusahaan yang kurang ideal. Efikasi diri dapat memengaruhi kinerja seseorang. Efikasi diri dapat menyebabkan seseorang lebih sukses (Hinton, Simpson, \& Smith, 2008).

Efikasi diri menumbuhkan keyakinan diri, memupuk harapan-harapan positif dalam diri karyawan. Efikasi diri dapat mendorong karyawan untuk tetap merasa yakin terhadap karirnya di tempat kerja. Memiliki ketenangan dalam menjalani karirnya di tempat kerja meskipun dengan sistem karir yang terbatas. Karyawan tetap menjalankan tugas dan pekerjaannya sehari-hari tanpa melihat ketidaknyamanan pada sistem karir di dalam organisasi (Higgins, Dobrow, \& Roloff, 2010). Karyawan dapat memelihara harapan-harapan positif untuk memberikan kontribusi yang terbaik bagi perusahaan. Karyawan juga memiliki pendangan masa depan yang cerah untuk dapat bekerja dengan baik untuk karirnya di perusahaan sekarang ataupun di tempat lain nantinya.

Berdasarkan uraian tersebut di atas peneliti tertarik untuk membuktikan secara empirik apakah dengan konsep efikasi diri dapat meningkatkan optimisme terhadap pencapaian karir karyawan PKWT yang bekerja di perusahaan. Dalam penelitian ini, efikasi diri sebagai bentuk intervensi psikologis dalam upaya meningkatkan optimisme terhadap pencapaian karir karyawan di tempat kerja.

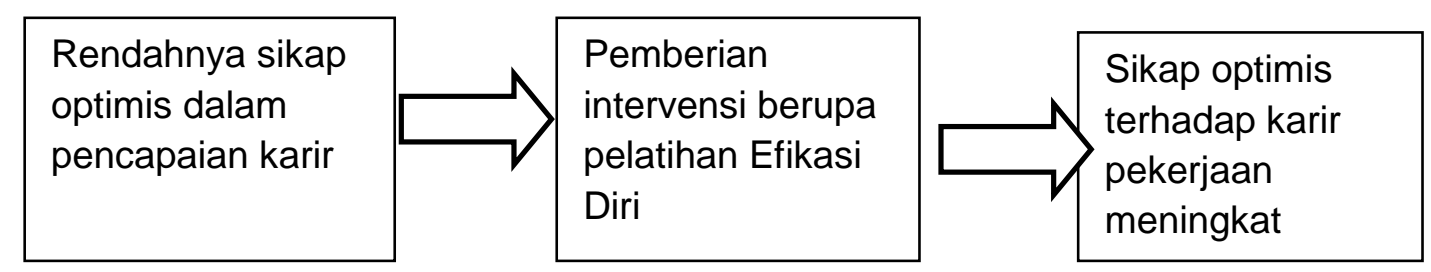

Gambar 1. Kerangka Penelitian

\section{METODE PENELITIAN}

\section{Subjek Penelitian}

Subjek dalam penelitian ini adalah karyawan PKWT perusahaan $X$ dengan kriteria memiliki masa kerja lebih dari tiga bulan berjumlah 50 orang. Pemilihan kriteria dan parameter populasi ini sebagai bentuk homogenitas kelompok subjek yang diukur dan diberikan pelatihan. 


\section{Rancangan Penelitian}

Metode penelitian yang digunakan adalah metode eksperimen. Desain eksperimen yang digunakan adalah the one group pretest and posttest design (Shadish, Cook \& Campbell, 2002). Penelitian ini menggunakan satu kelompok subjek. One group pretest and posttest design, yaitu desain eksperimen yang dilakukan prates sebelum diberikan perlakuan, dan dilakukan pascates setelah diberikan perlakuan. Hasil perlakuan dapat diketahui dengan lebih akurat, karena dapat membandingkan kondisi antara sebelum dengan sesudah diberi perlakuan.

\section{Metode Pengumpulan Data}

Metode pengumpulan data menggunakan alat ukur berupa angket penelitian. Pengumpulan data dilakukan dengan menggunakan angket efikasi diri dan optimisme terhadap pencapaian karir.

Angket Optimisme Terhadap Pencapaian Karir. Optimisme terhadap pencapaian karir dapat diukur dengan menggunakan alat ukur yang dikembangkan oleh Rottinghaus, Day, dan Borgen (2005). Aspek-aspek optimisme karir tersebut meliputi karakteristik dasar untuk (1) mengharapkan suatu kemungkinan yang terbaik dalam karir pekerjaannya, (2) merasa yakin terhadap suatu hal yang positif bagi pengembangan karir masa depannya dan (3) merasa nyaman dalam perencanaan karir yang dijalankan. Angket Optimisme pencapaian karir terdiri atas 26 item yang dinyatakan valid dari 36 item yang diuji coba, dengan rentang indeks daya beda antara 0,317 sampai dengan 0,589. Nilai koefisien reliabilitas alpha cronbach (a) sebesar 0,886 .

Angket Efikasi diri. Pengukuran efikasi diri didasarkan pada faktor-faktor pembentukan dimensi efikasi diri yang disusun berdasarkan teori Bandura (1982, 1993, 1997, 2006). Konstruk alat ukur efikasi diri terdiri dari magnitude (level), strength, dan generality. Angket Efikasi diri terdiri atas 16 item yang dinyatakan valid dari 32 item yang diuji coba, dengan rentang indeks daya beda antara 0,378 sampai dengan 0,657. Nilai koefisien reliabilitas alpha cronbach (a) sebesar 0,887

\section{Prosedur Intervensi}

Penelitian ini menggunakan satu kelompok eksperimen yang diberikan perlakuan sebagai bentuk intervensi. Pemberian intervensi ini berupa pelatihan efikasi diri. Pelatihan ini diberikan pada satu kelompok eksperimen yang dikenakan perlakuan yang sama. Satu minggu sebelum diberikan intervensi, kelompok (subjek) diukur menggunakan angket efikasi diri dan optimisme terhadap pencapaian karir (prates). Setelah diberikan intervensi kemudian diukur menggunakan alat ukur yang sama untuk mengukur efikasi diri dan optimisme terhadap pencapaian karir.

Intervensi diberikan kepada subjek dengan memberikan pelatihan selama dua hari dalam durasi waktu 4 (empat) 
jam sesuai dengan prosedur pelatihan. Pemberian intervensi dilakukan supaya karyawan memahami dan memunculkan efikasi diri dalam dirinya sehingga dapat terus bekerja dengan baik sesuai dengan visi dan misi dari perusahaan. Intervensi dalam penelitian ini didesain dalam bentuk pelatihan.
Kisi-kisi modul intervensi mengacu pada konsep yang dituliskan oleh Upton (1997). Aplikasi program pelatihan efikasi diri tersebut mencakup (1) Pembelajaran dari pemodelan (figur), (2) Pemantauan diri dan umpan balik, dan (3) Pencapaian tujuan (goal setting).

\section{Tabel 1. Kisi-Kisi Pelatihan Efikasi Diri}

\section{Hari Pertama}

\begin{tabular}{|c|c|c|c|c|}
\hline Sesi & $\begin{array}{l}\text { Kompetensi } \\
\text { Dasar }\end{array}$ & Topik Bahasan dan Materi & $\begin{array}{l}\text { Strategi } \\
\text { Belajar }\end{array}$ & $\begin{array}{l}\text { Alokasi } \\
\text { Waktu }\end{array}$ \\
\hline 1 & $\begin{array}{l}\text { Building } \\
\text { Rapport } \\
\text { Antara peserta } \\
\text { dengan } \\
\text { fasilitator }\end{array}$ & $\begin{array}{ll}\text { 1. } & \text { Perkenalan diri } \\
\text { 2. Kontrak belajar } \\
\text { 3. Overview materi } \\
\text { 4. Strategi pembelajaran } \\
\text { 5. Ice breaking }\end{array}$ & $\begin{array}{l}\text { Ceramah } \\
\text { Tanya } \\
\text { Jawab }\end{array}$ & $\begin{array}{c}30 \\
\text { menit }\end{array}$ \\
\hline 2 & $\begin{array}{l}\text { Pencapaian } \\
\text { tujuan (goal } \\
\text { setting career) }\end{array}$ & $\begin{array}{l}\text { 1. Visi dan Misi Perusahaan } \\
\text { 2. Strategy Planning } 2013\end{array}$ & $\begin{array}{l}\text { Ceramah } \\
\text { Tanya } \\
\text { Jawab }\end{array}$ & $\begin{array}{c}120 \\
\text { menit }\end{array}$ \\
\hline \multicolumn{3}{|c|}{ Istirahat (break) } & & 10 menit \\
\hline 3 & $\begin{array}{l}\text { Pemantauan } \\
\text { diri dan } \\
\text { umpan balik }\end{array}$ & $\begin{array}{l}\text { 1. Integrasi visi dan misi } \\
\text { perusahaan ke dalam diri } \\
\text { karyawan } \\
\text { 2. Company profile review } \\
\text { dan pengembangan bisnis }\end{array}$ & $\begin{array}{l}\text { Ceramah } \\
\text { Tanya } \\
\text { Jawab } \\
\text { Film }\end{array}$ & $\begin{array}{c}90 \\
\text { menit }\end{array}$ \\
\hline
\end{tabular}

\section{Hari Kedua}

\begin{tabular}{llllc}
\hline Sesi & $\begin{array}{l}\text { Kompetensi } \\
\text { Dasar }\end{array}$ & Topik Bahasan dan Materi & $\begin{array}{l}\text { Strategi } \\
\text { Belajar }\end{array}$ & $\begin{array}{c}\text { Alokasi } \\
\text { Waktu }\end{array}$ \\
\hline - & Building & 1. Perkenalan diri & Ceramah & 30 \\
& Rapport & 2. Kontrak belajar & Tanya & menit \\
Antara peserta & 3. Overview materi & Jawab & \\
$\begin{array}{l}\text { dengan } \\
\text { fasilitator }\end{array}$ & 4. Strategi pembelajaran & & \\
\hline
\end{tabular}




\begin{tabular}{|c|c|c|c|c|}
\hline 4 & $\begin{array}{l}\text { Pembelajaran } \\
\text { pemodelan } \\
\text { (figur) dan } \\
\text { penilaian diri }\end{array}$ & $\begin{array}{l}\text { 1. Bussiness overview } \\
\text { 2. Experience Sharing } \\
\text { tentang berkarir di } \\
\text { perusahaan oleh } \\
\text { Pimpinan }\end{array}$ & $\begin{array}{l}\text { Ceramah } \\
\text { Tanya } \\
\text { Jawab }\end{array}$ & $\begin{array}{c}120 \\
\text { menit }\end{array}$ \\
\hline \multicolumn{3}{|c|}{ Istirahat (break) } & & 10 menit \\
\hline 5 & $\begin{array}{l}\text { Refleksi dan } \\
\text { penguatan diri }\end{array}$ & $\begin{array}{l}\text { Sharing tentang insight } \\
\text { yang didapat. } \\
\text { Penguatan keyakinan diri } \\
\text { sebagai modal psikologis } \\
\text { dalam bekerja }\end{array}$ & $\begin{array}{l}\text { Ceramah } \\
\text { Tanya } \\
\text { Jawab }\end{array}$ & $\begin{array}{c}90 \\
\text { menit }\end{array}$ \\
\hline
\end{tabular}

\section{Metode Analisis Data}

Metode analisis data yang digunakan dalam penelitian ini adalah metode statistik parametrik. Teknik analisis yang digunakan untuk menguji hipotesis adalah Paired Sampel $t$ Test. Analisis Paired Sampel $t$ Test dilakukan untuk membandingkan dan mengetahui perbedaan optimisme pencapaian karir karyawan sebelum dan sesudah dilakukan intervensi. Analisis data dilakukan dengan bantuan program computer SPSS 16.

\section{HASIL PENELITIAN}

\section{Deskripsi Data}

Berdasarkan hasil analisis data didapatkan perbedaan selisih rata-rata pascates dan prates $=3,38$ dan nilai thitung sebesar 3,595 dan nilai signifikansi $=0,001<$ Level of Significant $=0,05$. Hal ini berarti ada perbedaan optimisme terhadap pencapaian karir karyawan PKWT perusahaan $X$ yang sangat signifikan antara sebelum dan setelah diberikan pelatihan efikasi diri. Nilai thitung sebesar 3,595 menunjukan bahwa terdapat peningkatan skor optimisme terhadap pencapaian karir karyawan setelah diberikan perlakuan berupa pelatihan.

Tabel 2. Mean Prates-Pascates Optimisme Terhadap Pencapaian Karir

\begin{tabular}{cccc}
\hline Kelompok & Mean Prates & Mean Postest & Mean Difference \\
\hline Eksperimen & 86,92 & 90,30 & 3,38 \\
\hline
\end{tabular}

Tabel 3. Hasil Uji Paired Sample t Test Optimisme Terhadap Pencapaian Karir

\begin{tabular}{ccccc}
\hline Variabel & $\mathrm{db}$ & Nilai $-\mathrm{t}$ & Sig. & Keterangan \\
\hline Prates-Pascates & 49 & 3,595 & 0,001 & Signifikan \\
\hline
\end{tabular}


Dari data tabel 3 dapat dikatakan bahwa terdapat perbedaan yang signifikan terhadap optimisme terhadap pencapaian karir karyawan PKWT perusahaan $\mathrm{X}$ antara sebelum dan setelah diberikan pelatihan efikasi diri.

\section{PEMBAHASAN}

Hasil analisis Paired Sample $t$ Test menunjukkan bahwa nilai signifikansi = $0,001<$ Level of Significant $=0,05$. Hal ini berarti terdapat perbedaan yang signifikan pada variabel optimisme pencapaian karir karyawan PKWT di perusahaan $X$ sebelum dan setelah diberikan intervensi berupa pelatihan efikasi diri. Pemberian pelatihan efikasi diri merupakan salah satu aspek penting dalam pencapaian karir seseorang di tempat kerja.

Pelatihan efikasi diri dapat membantu meningkatkan sikap optimis seseorang dalam pencapaian karir yang akan dicapai di suatu perusahaan. Karyawan menjadi yakin dengan tujuan pencapaian karir di masa depan. la juga menjadi yakin dengan potensi besar yang dimilikinya dalam usaha-usaha pencapaian kesuksesan karir. Karyawan mendapatkan insight atas pembelajaran sosial terhadap orang-orang yang telah sukses berkarir di bidangnya.

Pentingnya pemberian konsep efikasi diri dapat menumbuhkan rasa yakin dan optimis untuk dapat berkarir dalam fungsi pekerjaannya. Karyawan yang memiliki efikasi diri maka terbukti dapat memiliki optimisme terhadap pencapaian karir yang baik. Karyawan dapat meningkatkan sikap optimis terhadap kesuksesan karirnya dengan mempelajari komponen-kompenen efikasi diri yang dirancang dalam modul pelatihan penelitian ini.

Komponen pertama dalam modul pelaksanaan pelatihan efikasi diri menunjukkan bahwa karyawan dapat melakukan pembelajaran organisasi melalui visi dan misi perusahaan. Karyawan dapat menyerap dengan baik visi dan misi perusahaan agar sejalan dengan tujuan yang dimiliki. Karyawan dapat mendayagunakan potensi yang ada di dalam dirinya untuk menjadi karyawan yang sukses di tempat kerja. Karyawan dapat menentukan tujuan (goal setting) dalam dirinya untuk pencapaian karir. Hal tersebut menjadi modal sumber daya yang tumbuh dalam diri pribadi untuk mencapai karir yang optimal.

Pemberian pelatihan efikasi diri dapat membantu karyawan dalam memberikan penerimaan positif terhadap status kontrak yang dipersepsikan kurang ideal bagi karirnya. Karyawan terdorong untuk berpikiran terbuka menghadapi tantangan-tantangan resiko yang dapat menghambat karirnya. Karyawan dapat memiliki persepsi positif terhadap rutinitas penyelesaian pekerjaan dengan fokus pada tujuan karir yang akan dicapai di perusahaan tempat bekerja. 
Pada akhirnya muncul keinginan untuk terus bertahan dengan keyakinan diri yang dimiliki terhadap status masa kontrak yang dijalankannya. Karyawan memiliki anggapan positif jika dengan kondisi sistem kontrak ini tidak bagus maka ini adalah tantangan yang harus dihadapi dengan kuat berlandaskan tujuan karir (goal seeting) ataupun potensi yang dimiliki. Hal ini sejalan dengan pendapat yang diungkapkan oleh Bandura (1982, 1997) jika individu yang memiliki efikasi diri dalam karirnya maka akan memengaruhi pembelajarannya dalam bekerja menyelesaikan tugas pekerjaannya, memiliki tujuan yang akan dicapai dengan usaha dan keyakinannya, serta menumbuhkan persistensi dalam menghadapi kesulitan tugas.

Pelatihan dengan menggunakan konsep efikasi diri dapat membantu seseorang dalam menentukan tujuan (goal setting) bagi pencapaian karir pada masa mendatang. Sejalan dengan penelitian yang dilakukan oleh Avey, Luthans, dan Jansen (2008) yang salah satu komponennya berfokus pada efikasi diri. Hasil penelitiannya membuktikan bahwa efikasi diri mampu memberikan proyeksi-proyeksi positif untuk kesuksesan karir, rasa optimis pencapaian goal, tahapan pencapaian kesuksesan serta tantangantantangan yang harus dihadapi untuk mencapai kesuksesan karir dalam pekerjaannya.

Karyawan menjadi yakin dalam menjalankan pekerjaan sehari-hari dengan penuh semangat. la memiliki motivasi untuk tetap optimis berkarir di dalam organisasi dengan menunjukkan kinerja yang maksimal. Karyawan dapat membantu mengembangkan bisnis perusahaan sesuai dengan tujuan bisnis. Karyawan mampu menyelaraskan visi dan misi perusahaan sesuai dengan tujuan karirnya. Karyawan menjadi semangat untuk terus menerus berkarir sesuai perkembangan perusahaan. Pengaruh efikasi diri dan optimisme dapat menumbuhkan komitmen karyawan untuk bekerja secara terus menerus di dalam organisasi (Saleem, Saba, \& Adnan, 2012).

Pemahaman mengenai efikasi diri dapat membantu karyawan dalam memunculkan optimisme yang tinggi terhadap pekerjaan dan karirnya di perusahaan. Karyawan harus memahami bahwa konsep efikasi diri sebagai bentuk penguatan positif dalam menjalani tugas dan pekerjaan. Penelitian ini sejalan dengan penelitian yang dilakukan oleh Saleem, Saba, dan Adnan (2012). Hasil penelitiannya mengungkapkan bahwa efikasi diri dan optimisme memiliki korelasi dalam memunculkan keyakinan terhadap penguatan harapan-harapan positif akan kesuksesan. Seseorang yang merasa yakin maka dapat memunculkan harapan-harapan positif akan keberhasilan pada masa mendatang. Karyawan yang memiliki keyakinan yang kuat maka akan mengeluarkan segala daya kemampuannya untuk tujuan karir yang dapat dicapai pada masa mendatang.

Hasil dari pemberian pelatihan efikasi diri menyebabkan seseorang 
menjadi yakin dengan potensi besar yang dimilikinya dalam usaha-usaha pencapaian kesuksesan karir. Hal ini sejalan dengan penelitian yang dilakukan oleh Hinton, Simpson, dan Smith (2008). Hasil penelitiannya mengungkapkan bahwa efikasi diri dapat menyebabkan seseorang lebih sukses. Seseorang menyadari akan potensi positif yang ada di dalam dirinya. Potensi tersebut sebagai modal utama dalam memunculkan usahausaha nyata dalam bekerja.

Performa dan potensi dalam diri individu dapat memengaruhi kesuksesan karir di tempat kerja (Friedman, Kane, \& Cornfiled, 1998; Luthans, Avolio, Walumbwa, \& Li, 2005; Winarno, 2007). Dengan potensinya tersebut, seseorang dapat mengukur kemampuan yang dimiliki terhadap tujuan yang akan dicapai. Apabila ternyata kemampuan yang ada di dalam dirinya lebih besar dari tuntutan yang dicapai, maka memunculkan optimisme yang tinggi untuk berhasil. Pencapaian keberhasilan tersebut sebagai tolak ukur kesuksesan seseorang dalam pencapaian sesuatu.

Sejalan dengan penelitian yang dilakukan oleh Haselden, Sanders, dan Sturkie (2012) mengungkapkan bahwa model intervensi efikasi diri dapat meningkatkan faktor pencapaian prestasi. Karyawan akan terdorong untuk bertindak sesuai dengan tujuan yang diinginkan. Karyawan berusaha dengan sebaikbaiknya untuk mencapai sesuatu yang lebih baik. Karyawan termotivasi terhadap suatu hal yang ingin dicapai dengan baik.
Karyawan merasa yakin akan pencapaian yang diinginkan berdasarkan usaha-usaha untuk mencapai keberhasilan tersebut.

Hasil penelitian ini juga sejalan dengan Bandura (2006) yang mengungkapkan bahwa efikasi diri memengaruhi optimisme atau pesimisme seseorang. Karyawan merasa yakin dengan usaha-usaha yang dilakukan akan mendapatkan hasil yang positif. Proses kerja yang dilakukan hari ini dapat menghasikan sesuatu hal yang lebih baik pada masa mendatang. Keyakinan diri yang dimiliki membuat karyawan memiliki pemikiran terbuka bahwa hasil yang didapatkan nanti pastilah sesuai dengan usaha keras yang dilakukan saat ini. Konsep efikasi diri dapat menyebabkan seseorang merasa optimis dengan apa yang akan dilakukannya dapat menjadikannya berhasil.

Karyawan yang memiliki efikasi diri juga memiliki sifat optimis yang kemudian memunculkan usaha-usaha untuk bekerja (Hodges, 2010; Saleem, Saba, \& Adnan, 2012). Sejalan dengan pendapat yang dituliskan oleh Ballout (Wulandari, 2012) bahwa individu yang memiliki efikasi diri tinggi dalam membuat tujuan karir yang lebih tinggi akan memberikan usaha yang lebih dan mengejar strategi karir untuk mencapai tujuan tersebut. Karyawan dengan efikasi diri tinggi memiliki rasa optimis untuk tetap bekerja mencapai kesuksesan dalam karirnya. Sebaliknya karyawan dengan efikasi diri rendah, maka cenderung mengarah kepada keyakinan negatif, tidak 
ingin berusaha, dan merasa ragu untuk meraih kesuksesan dalam karirnya di dalam organisasi.

Efikasi diri dapat mendorong karyawan untuk tetap merasa yakin terhadap karirnya di tempat kerja. Karyawan memiliki ketenangan dalam menjalani karirnya di tempat kerja karena mengetahui tingkat keberhasilan pada masa mendatang. Karyawan tetap menjalankan tugas dan pekerjaannya sehari-hari dengan menghadapi berbagai tantangan. Karyawan dapat memelihara harapan-harapan positif untuk memberikan kontribusi yang terbaik bagi perusahaan. Hal ini sejalan dengan yang dijabarkan konsep harapan dalam perspektif islam dengan istilah ar-raja'. Ghazali (1997) menjelaskan bahwa seseorang yang memiliki harapan jika memiliki suatu kesenangan di dalam hati. Kesenangan hati itu sebagai bentuk kepuasan hati terhadap penantian yang disukai yang memiliki sebab. Kepuasan hati tersebut memunculkan keteguhan dan ketaatan untuk berusaha. Seseorang yang memiliki harapan di dalam hatinya, maka mampu memelihara usahausahanya secara terus menerus hingga mencapai sesuatu yang diharapkan.

Karyawan juga memiliki pandangan masa depan yang cerah untuk dapat bekerja dengan baik untuk karirnya di perusahaan sekarang ataupun di tempat lain nantinya. Hal tersebut memunculkan kepercayaan diri yang tinggi bahwa dirinya memiliki potensi karir yang berkualitas sesuai dengan kemampuan yang ditunjukkannya.

Pengaruh efikasi diri terbukti valid (tepat dan valid) dapat meningkatkan optimisme pencapaian karir pada karyawan. Hasil dari penelitian ini menunjukkan bahwa variabel optimisme terhadap pencapaian karir dapat dipengaruhi oleh variabel efikasi diri. Pada dasarnya pelatihan efikasi diri memberikan berbagai macam pengetahuan dan pemahaman serta informasi yang dibutuhkan oleh individu untuk meningkatkan potensi diri yang dimiliki. Potensi diri tersebut terkait dengan efikasi diri terhadap pekerjaannya saat ini untuk membantu dalam pencapaian karir masa depan. Pada pelatihan efikasi diri ini, individu difasilitasi untuk belajar tentang pentingnya efikasi diri terhadap visi dan misi pribadi maupun organisasi, efikasi diri terhadap tujuan karir, serta pembelajaran empirik mengenai efikasi diri yang dimiliki orang-orang yang sukses berkarir di perusahaan tersebut. Pembelajaran dalam pelatihan ini lebih berorientasi pada sharing terkait pengalaman-pengalaman yang dijumpai dalam pekerjaan.

\section{SIMPULAN DAN SARAN}

\section{Simpulan}

Berdasarkan rangkaian penelitian yang telah dilakukan, diperoleh hasil bahwa ada pengaruh yang sangat signifikan peningkatan optimisme pencapaian karir dengan diberikan pelatihan efikasi diri. Karyawan yang diberikan 
pelatihan efikasi diri telah terbukti mengalami peningkatan optimisme terhadap pencapaian karir.

Peningkatan optimisme terhadap pencapaian karir dapat dilakukan dengan melakukan pemodelan sosial terhadap figur karyawan yang sukses dalam berkarir di perusahaan, pencapaian tujuan karir (goal setting) dan proses pemantauan diri terhadap potensi diri yang dimiliki. Model intervensi menggunakan ketiga proses pembelajaran tersebut sebagai bagian dari efikasi diri telah terbukti mampu meningkatkan optimisme terhadap pencapaian karir pada karyawan.

\section{Saran}

Berkaitan dengan hasil penelitian ilmiah ini, maka merekomendasikan beberapa saran sebagai berikut. Pertama, bagi perusahaan, hendaknya menggunakan konsep efikasi diri dalam meningkatkan optimisme terhadap pencapaian karir dalam bentuk pelatihan kepada karyawan. Pelatihan tidak hanya membantu karyawan dalam memperoleh informasi tentang perusahaan, tetapi dengan adanya pembelajaran organisasi, goal setting dan penguatan positif dapat memotivasi para karyawan untuk meningkatkan optimisme terhadap karirnya, serta berkomitmen tinggi di dalam organisasi.

Kedua, bagi karyawan, sebaiknya setelah mengetahui pentingnya efikasi diri dari hasil pemberian pelatihan, karyawan dapat meningkatkan optimisme terhadap pencapaian karir sesuai dengan harapan perusahaan untuk arah transformasi bisnis ke depan.

Ketiga, bagi Implementasi di tempat kerja, hasil asesmen dan program yang telah dirancang dapat dijadikan sebagai pedoman melakukan intervensi melalui pelatihan untuk_meningkatkan aspek karir karyawan. Hal ini dapat dijadikan sebagai program penting bagi karyawan untuk pelaksanaan intervensi pada waktu yang akan datang.

\section{DAFTAR PUSTAKA}

Asri, M. (2008). Faktor yang menyebabkan turn over pada karyawan (artikel online). Diunduh pada 9 Februari 2013, dari http://www.kabarindonesia.com.

Avey, J. B., Luthans, F., \& Jensen, S. M. (2008). Psychological Capital: A Positive Resources For Combating Employee Stress And Turnover. The Journal of Human Resources Management, 48 (5), 677-693.

Avey, J. B., Reichard R. J., Luthans, F. \& Mhatre, K. (2011). Meta-Analysis Of The Impact Of Positive Psychological Capital On Employee Attitudes, Behaviors, And Performance. Journal of Human Resources Development Quarterly, 22 (2), 127-152.

Bandura, A. (1982). Self Efficacy Mechanism In Human Agency. 
Journal Of American Psychologist Associations Inc, 37 (2). 122-147.

Bandura, A. (1993). Perceived Self Efficacy In Cognitive Development and Functioning. Journal Of Educational Pychologist, 28 (2), 117-148.

Bandura, A. (1997). Self Efficacy. The Exercise of Control. New York: W.H Freeman and Company.

Bandura, A. (2006). Guide For Constructing Self Efficacy Scales. The Journal Self Efficacy Beliefs of Adolescents, 14, 307 - 337.

Bezt, N. \& Hacket, G. (2006). Career SelfEfficacy Theory: Back to the Future. The Journal of Career Assessment, 14 (1), $3-11$.

Carifio, J. \& Rhodes, L. (2002). Construct Validities And The Empirical Relationships Between Optimism, Hope, Self-Efficacy, And Locus Of Control. The Journal of Work, 19, 125-136.

Friedman, R., Kane, M., \& Cornfield, D. B. (1998). Social Support and Career Optimism: Examining the Effectiveness of Network Groups Among Black Managers. Journal of Human Relation, 51 (9), 11551177.
Ghazali, A. (1997). Mutiara Ihya Ulumuddin (Terjemahan). Cetakan Pertama. Bandung: Mizan.

Haselden, P., Sanders, M., \& Sturkie, L. (2012). Action Research: Effect of Self efficacy training on low achieving freshmen. Canadian of Journal Action Research, 13 (1), 335.

Higgins, M., Dobrow, S., \& Roloff, K. (2010). Optimism and the boundaryless career: The role of developmental relationships. Journal of Organizational Behavior, 31, 749-769.

Hinton, L., Simpson, G., \& Smith, D. (2008). Increasing Self-efficacy Beliefs in Middle School Students Using Quantum Learning Techniques. Research Educational Specialist Piedmont College. November 2008, 1-36.

Hodges, T. (2010). An Experimental Study of the Impact of Psychological Capital on Performance, Engagement, and the Contagion Effect. Dissertations and Theses from the College of Business Administration.

Kalnbach, L., \& Lantz, B. (1997). The Effects of Optimism and Willingness to Trust on Work-Related Attitudes and Behaviors: An Application to the Commercial Vehicle Industry. 
Department of Transportation, University Transportation Centers Program.

Luthans, F. (2002). The need for and meaning of positive organizational behavior. Journal of Organizational Behavior, 23, 695-706.

Luthans, F., Avey, J. B, Avolio, B. J., Norman, S. M., \& Combs, G. M. (2006). Psychological capital development: toward a micro-intervention. Journal of Organizational Behaviour, 27, 387-393.

Luthans, F., Avey, J. B., Avolio, B.J., \& Peterson, S. J. (2010). The Development and Resulting Performance Impact of Positive Psychological Capital. Journal of Human Resources Development Quarterly, 21 (1), 41-67.

Luthans, F., Avolio, B. J., Walumbwa, F. O., \& Li, W. (2005). The Psychological Capital of Chinese Workers: Exploring the Relationship with Performance. Journal of Management and Organization Review, 1 (2), 249-271.

Luthans, F., Luthans, K. W., \& Luthans, B. C. (2004). Positive psychological capital: Beyond human and social capital. Journal Business Horizons., 47 (1), 45-50.
Luthans, F., Norman, S. M, \& Avolio, B. J., \& Avey, J. B. (2008). The Mediating Role of Psychological Capital in the Supportive Organizational Climate - Employee Performance Relationship. Journal of Organizational Behavior, 1-46.

Luthans, F., \& Youssef, C. M. (2007). Emerging Positive Organizational Behavior. Journal of Leadership Institute Faculty Publications. 33 (3), 321-349.

Lyubomirsky, S., \& Boehm, J. K. (2005). Does Happines Promote Career Success. Journal of Career Assessment. 1-33.

Mathis, R. L. \& Jackson, J H. (2001). Manajemen Sumber Daya Manusia (Terjemahan). Jakarta: Salemba Empat.

Mathisen, G, E., \& Bronnick, K. S. (2009). Creative self-efficacy: An intervention study. International Journal of Educational Research.,48, 21-29.

Mortazavi, S., Yazdi, S. V., \& Amini, A. (2012). The Role of the Psychological Capital on Quality of Work Life And organization performance. Interdisciplinary Journal of Contempory Research In Business, 4 (2), 206-217. 
Rottinghaus, P. J., Day, S. X., \& Borgen, F. H. (2005). The Career Inventory: A Measure of Career-Related Adaptability and Optimism. Journal of Career Assessment, 13 (1), 1-24.

Saleem, A., Saba, G., \& Adnan, A. (2012). Self-efficacy And Optimism As Predictors of Organizational Commitment Among Bank Employees. International Journal of Research Studies in Psychology, 1, 1-10.

Shadish, W., Cook, T. and Campbell, D. (2002). Experimental and Quasi Experimental Designs for Generilized Causal Inference. Boston: Houghton Mifflin. Company.

Winarno. (2007). Pengaruh Human Capital, Motivasi dan Dukungan Supervisor Terhadap Kesuksesan Karir. Jurnal Kharisma, 1 (3) 265272.
Wright, T. (2003). The Positive organizational behavior: Incubator an idea whose time has truly come. Journal of Organizational Behavior, $24,437-442$.

Wulandari, E. R. (2012). Hubungan Antara Work-Family Conflict dan Big Five Personality dengan Career Self Efficacy. Calyptra Jurnal IImiah Mahasiswa Universitas Surabaya, 1 (1).

Owre, M. (2005). Career Self Efficacy And Career Decision Of AfricanAmerican, Hispanic And Anglo Students Enrolled In Selected Rural Texas High School. Dissertation of Educational Psychology.

Upton, S. (1997). Training Self Efficacy Beliefs In Doctoral Students. Advancing International Perspectives. Current Journal Research. Diunduh pada 18 Juni 2013 dari http://www.herdsa.org.au/wp.../199 7/uptons01 